\title{
Cadmium treatment effects on the growth and antioxidant system in barley plants under optimal and low temperatures
}

\author{
Natalia KAZNINA, Yulia BATOVA, Natalia REPKINA, Galina LAIDINEN, Alexandr TITOV
}

Received December 14, 2017; accepted February 03, 2018.

Delo je prispelo 14. decembra 2017, sprejeto 03. februarja 2018.

\begin{abstract}
The cadmium effect $(100 \mu \mathrm{M})$ on the barley (Hordeum

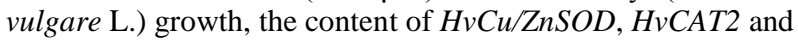
$H v P R X 07$ transcripts and the antioxidant enzymes activity (SOD, CAT and PRX) in roots and leaves of seedlings under optimal $\left(22{ }^{\circ} \mathrm{C}\right)$ and low $\left(4{ }^{\circ} \mathrm{C}\right)$ temperatures were studied. Exposure to cadmium at $22{ }^{\circ} \mathrm{C}$ did not inhibit the plants' growth. In this case, the rate of the oxidative processes in the cells remained at the control level. This was achieved by a corresponding increase of the gene transcripts and the antioxidant enzymes activity in roots and leaves. In contrast, exposure to cadmium at $4{ }^{\circ} \mathrm{C}$ inhibited the seedlings' growth despite of the lower metal content in the plants. Moreover the rate of lipid peroxidation in the roots and leaves increased significantly. It is assumed that this effect was connected with the accumulation of excess amounts of hydrogen peroxide due to a misbalance between its generation and neutralization. This assumption is confirmed by the obtained data, according to which the level of $H v C u / Z n S O D$ expression and the total activity of SOD increased significantly under exposure to cadmium at $4{ }^{\circ} \mathrm{C}$, although $H v C A T 2$ and $H v P R X 07$ transcripts and CAT and PXR activity did not rise.
\end{abstract}

Key words: Hordeum vulgare L.; cadmium; low temperature; growth; antioxidant enzymes; gene expression
IZVLEČEK

\section{UČINKI OBRAVNAVE S KADMIJEM NA RAST IN ANTIOKSIDACIJSKI SISTEM JEČMENA PRI OPTIMALNIH IN NIZKIH TEMPERATURAH}

Preučevan je bil učinek kadmija $(100 \mu \mathrm{M})$ na rast ječmena

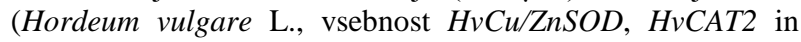
$H v P R X 07$ transkriptov in na aktivnost antioksidacijskih encimov (SOD, CAT in PRX) v koreninah in listih sejank pri optimalni $\left(22^{\circ} \mathrm{C}\right)$ in nizki temperaturi $\left(4{ }^{\circ} \mathrm{C}\right)$. Izpostavitev kadmiju pri $22^{\circ} \mathrm{C}$ ni zavrla rasti rastlin. $\mathrm{V}$ teh razmerah so oksidacijski procesi v celicah ostali na ravni kontrole, kar je bilo doseženo $\mathrm{s}$ povečanjem ustreznih prepisov genov in aktivnostjo antioksidacijskih encimov $\mathrm{v}$ koreninah in listih. Nasprotno je izpostavitev kadmiju pri $4{ }^{\circ} \mathrm{C}$ zavrla rast sejank kljub manjši vsebnosti kovine v rastlini. Peroksidacija maščob v koreninah in listih se je značilno povečala. Domnevamo, da je bil ta učinek povezan s kopičenjem presežnih količin vodikovega peroksida zaradi neuravnoteženosti njegovega nastanka in nevtralizacije. To domnevo potrjujejo podatki, da sta se ekspresija $H v C u / Z n S O D$ in celopkupna aktivnost SOD značilno povečali pri izpostavitvi kadmiju pri $4{ }^{\circ} \mathrm{C}$, pri čemer vsebnosti HvCAT2 in HvPRXO7 transkriptov in aktivnosti CAT ter PXR niso narasle.

Ključne besede: Hordeum vulgare L.; kadmij; nizke temperature; rast; antioksidacijski encimi; ekspresija genov

\section{INTRODUCTION}

One of the most harmful effects of adverse environmental factors on plants is the development of oxidative stress in cells, caused by the formation of an excessive amount of reactive oxygen species (ROS) (Foyer and Noctor, 2005; Gill and Tuteja, 2010). In small amounts, ROS are formed during metabolic processes and normally they are inactivated due to the components of antioxidant system. Under unfavorable conditions, the formation of ROS sharply increases, leading to oxidative stress, resulting in damage to proteins and nucleic acids, lipid oxidation and cell membrane damage, and eventually causing inhibition of plant growth and development, and sometimes their death (Avasthi et al., 2015). The same reaction is

Institute of Biology, Karelian Research Centre, Russian Academy of Sciences, 11 Pushkinskaya St., 185910 Petrozavodsk, Russia, corresponding author: batova@krc.karelia.ru 
observed in plants exposed to cadmium. Cadmium cannot directly generate ROS, but it causes their accumulation by mediating of disorders in the structure and functions of chloroplasts and mitochondria (Sandalio et al., 2001) or a decrease in the antioxidant enzymes activity (Schützendübel and Polle, 2002). At the same time it was found that the ability of some species (varieties, genotypes) to grow at high cadmium concentrations is largely due to the high activity of antioxidant system (AOS) components, which allows preserving the structural integrity and functional activity of cell membranes (Wu et al., 2003; Khan et al., 2007).

In recent years, the attention of researchers has been aimed at studying the influence of cadmium on antioxidant gene expression (Smeets et al., 2009; Luo et al., 2011). However, as a rule, such studies are conducted at optimum temperatures. At the same time, in the wild, especially in northern regions, in addition to heavy metal contamination, low temperatures during the growing season affect the growth and development of plants. As a result, as shown so far only in few studies, their metal resistance decreases, presumably due to a reduction of AOS components activity (Sergeant et al., 2014; Venzhik et al., 2015). In this connection, the purpose of this study was to investigate the effect of cadmium on the growth, the antioxidant gene transcripts content and the activity of antioxidant enzymes in the roots and leaves of barley, as one of the important cereal crops in the world, under optimal and low temperatures.

\section{MATERIALS AND METHODS}

\subsection{Plant growth conditions and treatments}

Barley seedlings (Hordeum vulgare 'Zazersky 85') were grown (water culture) for 7 days on nutrition solution with micronutrients in a growth chamber at $22{ }^{\circ} \mathrm{C}$ and $60-70 \%$ humidity under PAR $100 \mu \mathrm{mol}\left(\mathrm{m}^{2} \mathrm{~s}\right)^{-1}$ with $14 / 10 \mathrm{~h}$ light/dark regime. The composition of the basic nutrition solution: $\mathrm{NH}_{4} \mathrm{NO}_{3} 252 \mathrm{mg} / \mathrm{l}^{-1}, \mathrm{MgSO}_{4} \cdot 7 \mathrm{H}_{2} \mathrm{O}$ $187 \mathrm{mg} / \mathrm{l}^{-1}, \quad \mathrm{KH}_{2} \mathrm{PO}_{4} 210 \mathrm{mg} / \mathrm{l}^{-1}, \quad \mathrm{H}_{3} \mathrm{BO}_{3} 3 \mathrm{mg} / \mathrm{l}^{-1}$, $\mathrm{CuSO}_{4} \cdot 5 \quad \mathrm{H}_{2} \mathrm{O} \quad 1 \quad \mathrm{mg} / \mathrm{l}^{-1}, \quad \mathrm{MnSO}_{4} \cdot 5 \quad \mathrm{H}_{2} \mathrm{O} 3 \mathrm{mg} / /^{-1}$, $\mathrm{ZnSO}_{4} \cdot 7 \quad \mathrm{H}_{2} \mathrm{O} 0.5 \mathrm{mg} / \mathrm{l}^{-1},\left(\mathrm{NH}_{4}\right)_{6} \mathrm{Mo}_{7} \mathrm{O}_{24} 1 \mathrm{mg} / \mathrm{l}^{-1}, \mathrm{Fe}-$ citrate $10 \mathrm{mg} / \mathrm{l}^{-1}$. The solution $\mathrm{pH}=6.2$ was adjusted with $\mathrm{Ca}(\mathrm{OH})_{2}$. After that, the seedlings were exposed to cadmium at a concentration of $100 \mu \mathrm{mol}$ (as sulphate), which is sub-damaging for barley, at the optimum (22 $\left.{ }^{\circ} \mathrm{C}\right)$ and low $\left(4{ }^{\circ} \mathrm{C}\right)$ temperatures or at the $4{ }^{\circ} \mathrm{C}$ without cadmium. The control plants remained under the initial conditions. After $96 \mathrm{~h}$, the increment of length of the best developed root, shoot height, the underground and aboveground biomass were measured. The content of cadmium in the roots and leaves was analyzed. Along with this, the rate of lipid peroxidation was estimated by the accumulation of malondialdehyde (MDA). The $H v C u / Z n S O D, H v C A T 2$ and HvPRXO7 transcripts content and the activity of superoxide dismutase (SOD), catalase (CAT) and peroxidase (PRX) were also determined.

\subsection{Cadmium content assays}

The concentration of cadmium was measured by the method of inversion voltammetry using the polarograph ABC-1.1 (Volta, Russia). The decomposition of plant samples was carried out in a 4:1 mixture of $\mathrm{HNO}_{3}$ and
$\mathrm{H}_{2} \mathrm{O}_{2}$ using the microwave system of sample preparation MS-6 (Volta, Russia).

\subsection{Gene transcripts content}

The transcripts content of the genes involved in antioxidant cell defense was determined by qRT- PCR. For RNA isolation, the roots or leaves of barley $(50 \mathrm{mg})$ were ground in liquid nitrogen. Total RNA was isolated by ExtractRNA ("Eurogen"). The cDNA was synthesized using a reverse transcription kit with $\mathrm{M}$ MLV reverse transcriptase and random hexaprimers ("Eurogen"). The quantity and quality of the isolated RNA and synthesized cDNA were measured spectrophotometrically (SmartSpecPlus, "Bio-Rad"). Amplification was carried out in the iCycler with an iQ5 optical pre-amplifier ("Bio-Rad") using amplification kits with an intercalating SYBR Green dye ("Eurogen"). The $25 \mu \mathrm{l}$ PCR mixture contained $1 \mu \mathrm{l}$ of cDNA (100 ng), $5 \mu \mathrm{l}$ of the reaction mixture, $1 \mu \mathrm{l}$ of forward and reverse primers $(10 \mu \mathrm{mol})$ and $17 \mu \mathrm{l}$ of nuclease-free deionized water. Gene transcripts content was detected using the primers shown in the Table 1. Primers for qRT-PCR were made by "Labtech" (Russia). Actin was used as the reference gene. PCR protocol: $5 \mathrm{~min}$ at 95 ${ }^{\circ} \mathrm{C}$, then 45 cycles of $15 \mathrm{~s}$ at $95{ }^{\circ} \mathrm{C}, 50 \mathrm{~s}$ at $60{ }^{\circ} \mathrm{C}$. The specificity of the amplification products was checked by melting the PCR fragments: $1 \mathrm{~min}$ at $95{ }^{\circ} \mathrm{C}, 1 \mathrm{~min}$ at 60 ${ }^{\circ} \mathrm{C}, 10 \mathrm{~s}$ at $56{ }^{\circ} \mathrm{C}(80$ cycles, increasing the temperature by $0.5{ }^{\circ} \mathrm{C}$ in each cycle). The accumulation of gene transcripts was calculated from $\Delta \Delta$ St (Livak and Schmittgen, 2001). cDNAs isolated from plants not exposed to stress factors were selected as the control samples. 
Table 1: Primers for qRT-PCR

\begin{tabular}{|c|c|c|c|}
\hline Gene & Primer & $\begin{array}{c}\text { Nucleotide sequence } \\
5^{\prime} \ldots 3^{\prime}\end{array}$ & $\begin{array}{l}\text { Accession number in } \\
\text { NCBI GenBank }\end{array}$ \\
\hline \multirow[t]{2}{*}{$\mathrm{HvCu/ZnSOD}$} & forward & CCTGCCCTTTCCACTCG & HM537232 \\
\hline & reverse & TGTCGTAGGACCGTCATCG & \\
\hline \multirow[t]{2}{*}{ HvCAT2 } & forward & GACAAGTCGTGCGGGATG & HVU20778 \\
\hline & reverse & CCTTATTGCTGGCTGGTT & \\
\hline \multirow[t]{2}{*}{ HvPRX07 } & forward & TCСАСССТСАТСТССТССТТ & X62438 \\
\hline & reverse & ACGGCTTGAACGGTCCTC & \\
\hline
\end{tabular}

\subsection{Malondialdehyde content and antioxidant enzymes activity assays}

The MDA content and antioxidant enzymes activity were determined on a spectrophotometer (Spectrum, Russia). To analyze the MDA content, a reaction medium containing $0.25 \%$ solution of thiobarbituric acid (TBA) in $10 \%$ trichloroacetic acid was used according to Heath and Packer (1968). The plant material was homogenized in the reaction medium. The homogenate was aged in a water bath at $95{ }^{\circ} \mathrm{C}$ for 30 minutes, quickly cooled in an ice vessel and centrifuged for $10 \mathrm{~min}$ at $10,000 \mathrm{~g}$. The absorbance of the supernatant was measured at $\mathrm{D}=532$ and $600 \mathrm{~nm}$. The concentration of TBA-reacting products was calculated using the formula $\mathrm{C}_{\mathrm{MDA}}=\left(\mathrm{D}_{532}-\mathrm{D}_{600}\right) / \varepsilon \cdot \mathrm{m}$, where $\mathrm{C}_{\mathrm{MDA}}$ is the concentration of MDA ( $\mu \mathrm{mol} \mathrm{g}{ }^{-1}$ wet mass), $\mathrm{D}_{532}$ and $\mathrm{D}_{600}$ are the optical densities of the sample at the appropriate wavelengths, $\varepsilon$ is the MDA extinction coefficient equal to $155 \mathrm{mmol}^{-1} \mathrm{~cm}^{-1}$, $\mathrm{m}$ is the mass of the sample (g).

To determine the content of soluble proteins and the activity of antioxidant enzymes the plant material was homogenized in $0.1 \mathrm{M} \mathrm{K} / \mathrm{Na}$-phosphate buffer $(\mathrm{pH}=$ 7.8) at $2-4{ }^{\circ} \mathrm{C}$. The homogenate was centrifuged for 20 minutes at $15,000 \mathrm{~g}$ and $4{ }^{\circ} \mathrm{C}$. The supernatant was used for the analysis. The soluble protein content was determined by the Bradford method (Bradford, 1976) using bovine serum albumin as the standard.
The determination of the total activity of SOD (EC 1.15.1.1) was carried out according to Beauchamp and Fridovich (1971), based on the ability of SOD to inhibit the photochemical reduction of nitrogen tetrazolium to formazan. The amount of the enzyme capable of suppressing the reduction of nitrogen tetrazolium by $50 \%$ was taken as the unit of SOD activity. The activity of CAT (EC 1.11.1.6) was measured by the amount of decomposed hydrogen peroxide per unit time at $240 \mathrm{~nm}$ (Aebi, 1984). The enzyme activity was calculated using the extinction coefficient of hydrogen peroxide $(\mathrm{E}=36$ $\mathrm{mol}^{-1} \mathrm{~cm}^{-1}$ ). The PRX activity (EC 1.11.1.7) was measured by the increase in optical density at $470 \mathrm{~nm}$ as a result of guaiacol oxidation $\left(\mathrm{E}=26.6 \mathrm{mmol}^{-1} \mathrm{~cm}^{-1}\right)$ in the presence of hydrogen peroxide (Maehly and Chance, 1954).

\subsection{Statistical analysis}

Experiment was conducted in complete randomized design with 3 replications. Biological replication within each variant for different measurements was from 3 to 10 plants, analytical replication was 3-4-fold. Statistical processing of the data was carried out using the Microsoft Excel software package. The data are presented as the mean \pm standard error and were tested by paired Student's test at the $5 \%$ probability level.

\section{RESULTS}

\subsection{Plant growth}

The results showed that at a temperature of $22{ }^{\circ} \mathrm{C}$ cadmium has a minor effect on the growth of 7-day barley seedlings. There was only a shoot height increment (for $96 \mathrm{~h}$ ) decrease (by $35 \%$ of the control) (Table 2). However, this did not affect the plant biomass storage. The low temperature leads to inhibition of seedling growth.

All the growth parameters were lowered (compared to the control). The strongest decline in growth parameters was observed in the presence of cadmium. 
Table 2: Effect of cadmium $(100 \mu \mathrm{mol})$ on the barley growth under the optimum $\left(22{ }^{\circ} \mathrm{C}\right)$ and low $\left(4{ }^{\circ} \mathrm{C}\right)$ temperatures

\begin{tabular}{lcccc}
\hline \multirow{2}{*}{ Parameter } & \multicolumn{4}{c}{ Treatment } \\
\cline { 2 - 5 } & $22{ }^{\circ} \mathrm{C}$ & $\mathrm{Cd}^{2+}, 22{ }^{\circ} \mathrm{C}$ & $4{ }^{\circ} \mathrm{C}$ & $\mathrm{Cd}^{2+}, 4{ }^{\circ} \mathrm{C}$ \\
\hline Root length increment, $\mathrm{mm} / 96 \mathrm{~h}$ & $0.29 \pm 0.11 \mathrm{a}$ & $0.17 \pm .0 .05 \mathrm{a}$ & $0.23 \pm 0.04 \mathrm{a}$ & $0.05 \pm 0.02 \mathrm{~b}$ \\
Shoot height increment, $\mathrm{mm} / 96 \mathrm{~h}$ & $5.12 \pm 0.39 \mathrm{a}$ & $1.30 \pm 0.16 \mathrm{~b}$ & $0.39 \pm 0.04 \mathrm{c}$ & $0.25 \pm 0.03 \mathrm{c}$ \\
Root dry biomass increment, $\mathrm{mg} / 96 \mathrm{~h}$ & $2.06 \pm 0.49 \mathrm{a}$ & $1.65 \pm 0.35 \mathrm{a}$ & $0.74 \pm 0.41 \mathrm{ab}$ & $0.31 \pm 0.12 \mathrm{~b}$ \\
Shoot dry biomass increment, $\mathrm{mg} / 96 \mathrm{~h}$ & $7.45 \pm 1.44 \mathrm{a}$ & $7.35 \pm 0.96 \mathrm{a}$ & $3.71 \pm 1.37 \mathrm{ab}$ & $2.87 \pm 0.62 \mathrm{~b}$ \\
\hline
\end{tabular}

Values perform mean \pm SE $(\mathrm{n}=20) *$ Significant differences at $p<0.05$ from control level.

\subsection{Cadmium content}

Usually, the inhibition of plant growth at high cadmium concentrations is associated with its direct effect on cell division and elongation. In our experiments, however, after a four-day exposure to $4{ }^{\circ} \mathrm{C}$ temperature, the metal content in the roots and leaves of the seedlings was 3-4 times lower than at the optimum temperature (Table 3).

Table 3: Cadmium content ( $\mu \mathrm{g} / \mathrm{g} \mathrm{FM})$ in the barley root and leaves after $96 \mathrm{~h}$ exposure to metal $(100 \mu \mathrm{mol})$ at the optimum $\left(22^{\circ} \mathrm{C}\right)$ and low $\left(4^{\circ} \mathrm{C}\right)$ temperatures

\begin{tabular}{lcccc}
\hline \multirow{2}{*}{ Organ } & \multicolumn{4}{c}{ Treatment } \\
\cline { 2 - 5 } & $22{ }^{\circ} \mathrm{C}$ & $\mathrm{Cd}^{2+}, 22^{\circ} \mathrm{C}$ & $4{ }^{\circ} \mathrm{C}$ & $\mathrm{Cd}^{2+}, 4{ }^{\circ} \mathrm{C}$ \\
\hline Root & $0.02 \pm 0.001 \mathrm{a}$ & $43.21 \pm 2.50 \mathrm{c}$ & $0.02 \pm 0.001 \mathrm{a}$ & $16.61 \pm 0.87 \mathrm{~b}$ \\
Leaf & $0.02 \pm 0.001 \mathrm{a}$ & $5.52 \pm 0.52 \mathrm{c}$ & $0.03 \pm 0.001 \mathrm{a}$ & $2.26 \pm 0.013 \mathrm{~b}$ \\
\hline
\end{tabular}

Values perform mean $\pm \mathrm{SE}(\mathrm{n}=10) *$ Significant differences at $p<0.05$ from control level.

\subsection{Lipid peroxidation rate}

Since one of the main reasons for the slowing down of growth processes in plants under unfavorable environmental conditions is the formation of an excessive amount of ROS, we investigated the effect of cadmium on the lipid peroxidation rate in relation to temperature. It was found that under the cadmium at optimum temperature the MDA content slightly increased in the leaves and did not change in the roots, whereas at $4{ }^{\circ} \mathrm{C}$ it increases significantly both in the roots (by $73 \%$ of the control) and in the leaves (by $23 \%$ ) (Table 3). Interestingly, at low temperature without cadmium, the MDA content did not rise.

Table 4: Effect of cadmium $(100 \mu \mathrm{mol})$ on the MDA content and antioxidant enzymes activity in the roots and leaves of barley under the optimum $\left(22^{\circ} \mathrm{C}\right)$ and low $\left(4{ }^{\circ} \mathrm{C}\right)$ temperatures

\begin{tabular}{|c|c|c|c|c|c|}
\hline \multirow{2}{*}{ Parameter } & \multirow{2}{*}{ Organ } & \multicolumn{4}{|c|}{ Treatment } \\
\hline & & $22^{\circ} \mathrm{C}$ & $\mathrm{Cd}^{2+}+22{ }^{\circ} \mathrm{C}$ & $4^{\circ} \mathrm{C}$ & $\mathrm{Cd}^{2+}+4^{\circ} \mathrm{C}$ \\
\hline MDA content, & root & $2.56 \pm 0.14 a$ & $2.77 \pm 0.11 \mathrm{a}$ & $4.11 \pm 0.22 b$ & $4.42 \pm 0.16 b$ \\
\hline$\mu \mathrm{mol} \mathrm{g}{ }^{-1} \mathrm{FM}$ & leaf & $4.27 \pm 0.16 \mathrm{a}$ & $5.57 \pm 0.22 b$ & $4.39 \pm 0.16 \mathrm{a}$ & $5.26 \pm 0.22 b$ \\
\hline Total SOD activity, & root & $5.33 \pm 0.39 \mathrm{a}$ & $8.85 \pm 0.51 b$ & $13.69 \pm 1.93 c$ & $13.73 \pm 1.24 c$ \\
\hline units $\cdot \mathrm{mg}^{-1}$ protein & leaf & $2.60 \pm 0.24 \mathrm{a}$ & $3.99 \pm 0.22 b$ & $4.03 \pm 0.13 b$ & $3.93 \pm 0.30 \mathrm{~b}$ \\
\hline Total CAT activity, $\mu \mathrm{mol}$ & root & $5.93 \pm 0.81 \mathrm{a}$ & $17.59 \pm 2.27 b$ & $4.29 \pm 1.08 \mathrm{ac}$ & $2.78 \pm 0.53 c$ \\
\hline $\mathrm{H}_{2} \mathrm{O}_{2} \mathrm{~min}^{-1} \mathrm{mg}^{-1}$ protein & leaf & $39.90 \pm 5.73 a$ & $47.49 \pm 5.57 \mathrm{ab}$ & $22.93 \pm 2.09 \mathrm{~d}$ & $33.95 \pm 1.90 \mathrm{ac}$ \\
\hline Total PRX activity, $\mu \mathrm{mol}$ & root & $16.34 \pm 2.34 \mathrm{a}$ & $29.09 \pm 1.84 b$ & $17.56 \pm 1.70 \mathrm{a}$ & $21.26 \pm 2.24 \mathrm{a}$ \\
\hline $\begin{array}{l}\text { guaiacol } \mathrm{min}^{-1} \mathrm{mg}^{-1} \\
\text { protein }\end{array}$ & leaf & $2.34 \pm 0.24 \mathrm{a}$ & $8.72 \pm 1.13 b$ & $0.97 \pm 0.10 \mathrm{c}$ & $0.86 \pm 0.07 \mathrm{c}$ \\
\hline
\end{tabular}

Values perform mean $\pm \mathrm{SE}(\mathrm{n}=10) *$ Significant differences at $p<0.05$ from control level.

\subsection{Gene transcript content}

A low level of ROS in plants under stress is maintained owing to the efficient operation of AOS, including antioxidant enzymes. The most important role belongs to SOD, which catalyzes the dismutation of the superoxide anion radical reaction, as well as to CAT and PRX, which decompose the hydrogen peroxide (Foyer and Noctor, 2015). In our study, after $96 \mathrm{~h}$ of cadmium impact on barley seedlings at $22{ }^{\circ} \mathrm{C}$ in the roots the 
content of gene transcripts of all antioxidant enzymes increased practically equally (approximately 2 times) (Fig.). In leaves, the $H v C u / Z n S O D$ mRNA level did not change, while $H v C A T 2$ and $H v P R X 07$ also increased. In contrast, when seedlings exposed to cadmium at $4{ }^{\circ} \mathrm{C}$ the $\mathrm{HvCu} / \mathrm{ZnSOD}$ transcripts content increased in both roots and leaves, while the HvCAT2 and $H v P R X 07$ mRNA level did not change in the roots and even decreased in the leaves. Low temperature effect without cadmium led to an increase of the $H v C u / Z n S O D$ and HvPRX07 mRNA level.

A

$\square$-roots $\square$ - leaves

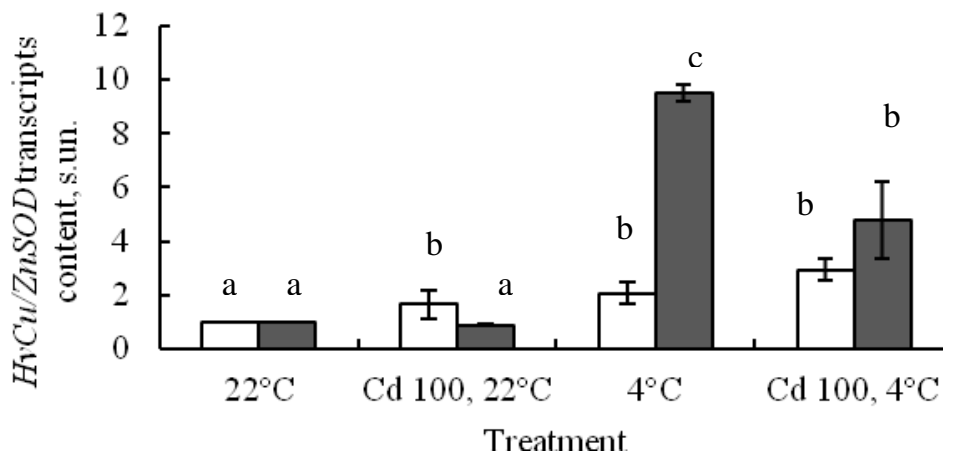

B

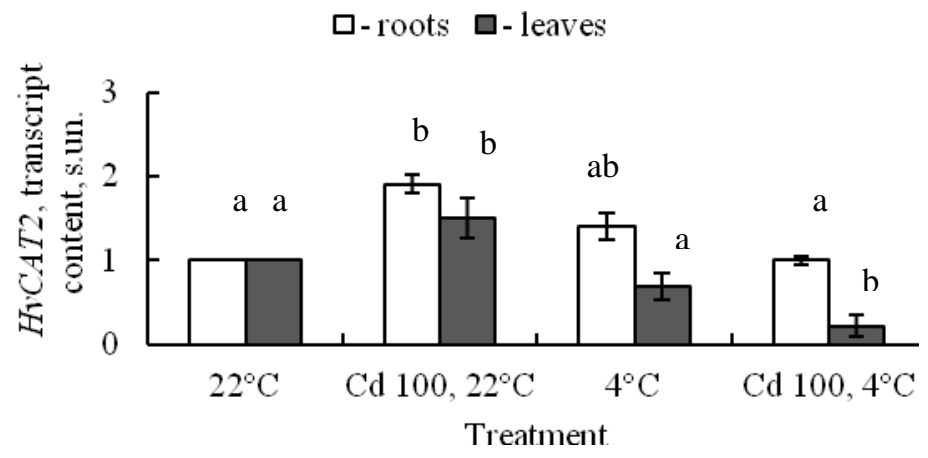

C

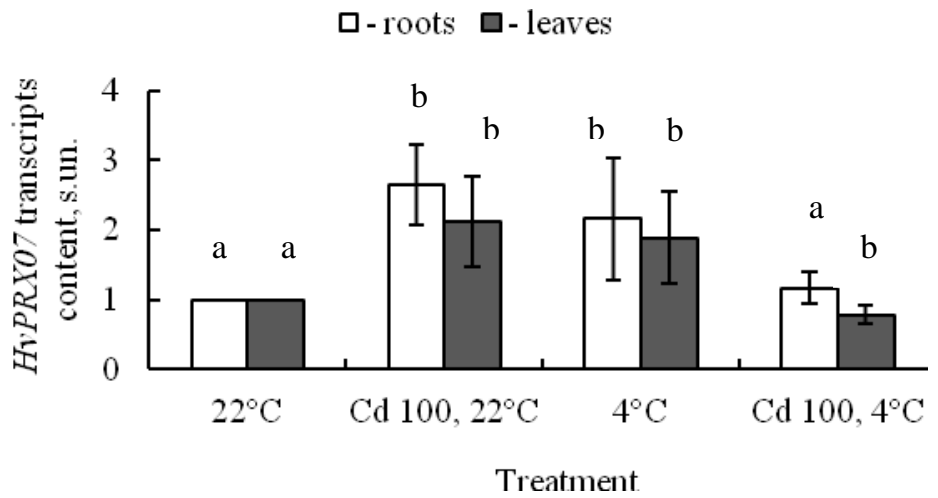

Figure 1: Effect of cadmium $(100 \mu \mathrm{mol})$ on the $H v C u / Z n S O D(\mathrm{~A}), H v C A T 2$ (B) and $H v P R X 07$ (C) transcripts level in the roots and leaves of barley seedlings under the optimum $\left(22^{\circ} \mathrm{C}\right)$ and low $\left(4{ }^{\circ} \mathrm{C}\right)$ temperatures 


\subsection{Antioxidant enzymes activity}

The change in the antioxidant enzymes activity in most cases corresponded to changes in the gene transcript content. For example, in the roots SOD and PRX activity in the presence of cadmium and under the optimum temperature increased almost two-fold compared to the control, and CAT activity increased three-fold (Table 3). At $4{ }^{\circ} \mathrm{C}$, on the other hand, SOD activity was significantly increased (tripled compared to the control), while PRX activity did not change and CAT activity decreased. In the leaves at $22{ }^{\circ} \mathrm{C}$ antioxidant enzymes activity was higher than in the control, while at low temperatures SOD activity increased three-fold and CAT and PRX activity significantly decreased (two- and three-fold, respectively). At a low temperature without cadmium only SOD activity was increased also.

\section{DISCUSSION}

It is known that plants are able to grow normally at high cadmium concentrations in the environment. This is possible due to a number of adaptation mechanisms at different organizational levels. Among them, the antioxidant system plays an important role. In our experiments, cadmium at the optimum temperature had no adverse effect on the growth of barley seedlings. The high cadmium resistance of the plants was partly due to owing the consistent rise of the antioxidant gene transcripts content and the activity of antioxidant enzymes in roots and leaves. As a result, there was no increase in the lipid peroxidation rate in the cells, indicating the absence of oxidative stress. Similar data were obtained by other authors. For example, in the roots and leaves of Arabidopsis thaliana (L.) Heynh. exposed to this metal there was an increase in the gene expression level of such antioxidant enzymes as ascorbate peroxidase (APX) and CAT (Smeets et al., 2008), in rice roots - glutathione-S-transferase, APX and glutathione reductase (GR) (Lee et al., 2010), in the leaves of Lolium perenne L. - Cu/ZnSOD, APX and GR (Luo et al., 2011), which was accompanied by an increase in the enzymes activity and contributed to the adaptation of the plants to cadmium.

Under exposure to cadmium at $4^{\circ} \mathrm{C}$, the growth of both roots and shoots of the seedlings was inhibited, despite the lower metal content in the plants. The cells experienced an acceleration of oxidative processes, as evidenced by an increased of lipid peroxidation rate. In this case, the $\mathrm{HvCu} / \mathrm{ZnSOD}$ transcripts content and the total activity of SOD in the roots and leaves increased significantly. At the same time, there was no rise of the HvCAT2 and HvPRXO7 mRNA level and the CAT and PRX activity. The fact that the activity of $\mathrm{H}_{2} \mathrm{O}_{2}$ decomposing enzymes was not enhanced under low temperatures has been mentioned in other studies. For example, APX activity in the leaves of a cold-resistant potato variety did not change at $5{ }^{\circ} \mathrm{C}$ (Sinkevich et al., 2011). In chilling-resistant varieties of tobacco (Gechev et al., 2003), barley, rice and wheat (Janda et al., 2003) exposed to $5{ }^{\circ} \mathrm{C}$ temperature a decrease in CAT activity was observed. In these cases the amount of hydrogen peroxide in the cells increased.

It is known that an agreed increase of the antioxidant enzymes activity is essential for maintaining the balance between the generation and neutralization of ROS (Gechev et al., 2003; Avasthi et al., 2015). Hence, the enhanced SOD activity alone, without an increase in the activity of CAT and/or PRX, as was observed in our experiments, leads to a build up of the hydrogen peroxide concentration in cells, and, accordingly, to an acceleration of oxidative processes. Probable development of oxidative stress in plants exposed to cadmium at low temperature was one of the reasons for the inhibition of their growth.

Attention must also be given to the high level of HvPRX07 transcripts and a significant increase in PRX activity in the seedlings' roots and leaves under exposure to cadmium at $22^{\circ} \mathrm{C}$. This effect may be associated with its various functions in the cell. For example, with its participation in the lignifications of cell walls, where they can provide additional protection of cells from the toxic ions and thereby contribute to an increase of metal resistance (Lukačová et al., 2013). Since at low temperature without cadmium all growth parameters changed to a lesser degree than in the presence of the metal, it can be assumed that with the combined action of low temperature and cadmium, their negative effects are summarized.

\section{CONCLUSIONS}

Thus, the effect of cadmium on the growth and antioxidant enzymes activity of barley seedlings is temperature-dependent. In the treatment with exposure to cadmium under optimal temperature the consistent increase of the $H v C u / Z n S O D, H v C A T 2$ and $H v P R X 07$ transcripts content and the activity of SOD, CAT and 
PRX prevented the development of oxidative stress in the cells, enabling the plants to grow normally at a high concentration of cadmium in the medium and in the plants' organs. In contrast, exposure to cadmium coupled with low temperature inhibited plant growth, since the lipid peroxidation rate in the roots and leaves was accelerated. The activation of oxidative processes in this case is likely to be connected with the accumulation of excess amounts of hydrogen peroxide due to a misbalance between its generation and neutralization.

\section{ACKNOWLEDGMENTS}

The study was carried out under state order (project No.

0221-2017-0051).

\section{REFERENCES}

Aebi, H. E. (1984). Catalase in vitro. Methods in Enzymology, 105, 121-126. doi:10.1016/S00766879(84)05016-3

Avasthi, R., Bhandari, K., Nayyar, H. (2015). Temperature stress and redox homeostasis in agricultural crops. Frontiers in Environmental Science, 3, 1-24. doi:10.3389/fenvs.2015.00011

Beauchamp, C., Fridovich, I. (1971). Superoxide dismutase: improved assays and an assay applicable to acrylamide gels. Analytical of Biochemistry, 44, 276-287. doi:10.1016/0003-2697(71)90370-8

Bradford, M. M. (1976). A rapid and sensitive method for the quantitation of microgram quantities of protein utilizing the principle of protein-dye binding. Analytical of Biochemistry, 72, 248-254. doi:10.1016/0003-2697(76)90527-3

Foyer, C.H., Noctor, G. (2005). Oxidant and antioxidant signaling in plants: a re-evaluation of the concept of oxidative stress in a physiological context. Plant, Cell and Environment, 29, 1056-1071. doi:10.1111/j.1365-3040.2005.01327.x

Foyer C. H., Noctor, G. (2015). Defining robust redox signalling within the context of the plant cell. Plant, Cell and Environment, 38, 239-239. doi:10.1111/pce.12487

Gechev, T., Willekens, H., Van Montagu, M., Inze, D., Van Camp, W., Toneva, V., Minkov, I. (2003) Different responses of tobacco antioxidant enzymes to light and chilling stress. Journal of Plant Physiology, 160, 509-515. doi:10.1078/0176-161700753

Gill, S. S, Tuteja, N. (2010). Reactive oxygen species and antioxidant machinery in abiotic stress tolerance in crop plants. Plant Physiology and Biochemistry. $\quad 48, \quad 909-930$. doi:10.1016/j.plaphy.2010.08.016
Heath, R. L., Packer, L. (1968). Photoperoxidation in isolated cloroplasts. Kinetics and stoichiometry of fatty acid peroxidation. Archives of Biochemistry and Biophysics, 125, 189-198. doi:10.1016/00039861(68)90654-1

Janda, T., Szalai, G., Rios-Gonzaier, K., Veisz, O., Páldi, E. (2003). Comparative study of frost tolerance and antioxidant activity in cereals. Plant Science, $\quad 164, \quad 301-306$. doi:10.1016/S01689452(02)00414-4

Khan, M. A., Samiullah, S., Singh, S., Nazar, R. (2007). Activities of antioxidative enzymes, sulphur assimilation, photosynthetic activity and growth of wheat (Triticum aestivum) cultivars differing in yield potential under cadmium stress. Journal of Agronomy and Crop Science, 193, 435-444. doi:10.1111/j.1439-037X.2007.00272.x

Lee, K., Bae, D.W., Kim, S. H., Han, H. J., Liu, X., Park, N. C., Lim, C. O., Lee, C. Y., Chung, W. S. (2010). Comparative proteomic analyses of the short-term responses of rice roots and leaves to cadmium. Journal of Plant Physiology, 167, 161168. doi:10.1016/j.jplph.2009.09.006

Livak, K. J., Schmittgen, T. D. (2001). Analysis of relative gene expression data using real-time quantitative PCR and the $2^{-\Delta \Delta \mathrm{Ct}}$ method. Methods, 25, 402-408. doi:10.1006/meth.2001.1262

Lukačová, Z., Švubová, R., Kohanová, J., Lux, A. (2013). Silicon mitigates the Cd toxicity in maize in relation to cadmium translocation, cell distribution, antioxidant enzymes stimulation and enhanced endodermal apoplasmic barrier development. Plant Growth Regulation, 70, 89-103. doi:10.1007/s10725-012-9781-4

Luo, H., Li, H., Zhang, X., Fu, J. (2011). Antioxidant responses and gene expression in perennial ryegrass (Lolium perenne L.) under cadmium stress. 
Ecotoxicology, 20, 770-778. doi:10.1007/s10646011-0628-y

Maehly, A. C., Chance, B. (1954). The assay of catalase and peroxidase. Methods of Biochemical Analysis, $1,357-424$.

Sandalio, L. M., Dalurzo, H. C., Gómez, M., RomeroPuertas, M. C., Del Rio, L. A. (2001). Cadmiuminduced changes in the growth and oxidative metabolism of pea plants. Journal of Experimental Botany, 52, 2115-2126. doi:10.1093/jexbot/52.364.2115

Schützendübel, A., Polle, A. (2002). Plant responses to abiotic stresses: heavy metal-induced oxidative stress and protection by mycorrhization. Journal of Experimental Botany. 53, 1351-1365. doi:10.1093/jexbot/53.372.1351

Sergeant, K., Kieffer, P., Dommes, J., Hausman, J.-F., Renaut, J. (2014). Proteomic changes in leaves of poplar exposed to both cadmium and lowtemperature. Environmental and Experimental Botany, 106, 112-123. doi:10.1016/j.envexpbot.2014.01.007

Sin'kevich, M. S., Naraikina, N. V., Trunova, T. I. (2011). Processes hindering activation of lipid peroxidation in cold-tolerant plants under hypothermia. Russian Journal of Plant Physiology, 58, 1020-1026. doi:10.1134/S1021443711050232

Smeets, K., Opdenakker, K., Remans, T., Van Sanden, S., Van Belleghem, F., Semane, B. (2009). Oxidative stress-related responses at transcriptional and enzymatic levels after exposure to $\mathrm{Cd}$ or $\mathrm{Cu}$ in a multipollution context. Journal of Plant Physiology, $\quad 166, \quad$ 1982-1992. doi:10.1016/j.jplph.2009.06.014

Smeets, K., Ruytinx, J., Semane, B., Van Belleghem, F., Remans, T., Van Sanden, S., Vanginsveld. J., Cuypers, A. (2008). Cadmium-induced transcriptional and enzymatic alterations related to oxidative stress. Environmental and Experimental Botany, 63, 1-8. doi:10.1016/j.envexpbot.2007.10.028

Venzhik, Yu. V., Talanova, V. V., Titov, A. F., Kholoptseva, E. S. (2015). Similarities and differences in wheat plant responses to low temperature and cadmium. Biology Bulletin, 42, 508-514. doi:10.1134/S1062359015060126

Wu, F., Zhang, G., Dominy, P. (2003). Four barley genotypes respond differently to cadmium: lipid peroxidation and activities of antioxidant capacity. Environmental and Experimental Botany, 50, 6778. doi:10.1016/S0098-8472(02)00113-2 